\title{
요로결석의 예방과 관리
}

\author{
정 해 도 ${ }^{1} \cdot$ 이 주 용 ${ }^{2}$
}

1원광대학교 의과대학 산본병원 비뇨의학과

${ }^{2}$ 연세대학교 의과대학 비뇨의학교실 비뇨의과학연구소

\section{Prevention and management of urinary stone}

\author{
Hae Do Jung, MD' - Joo Yong Lee, MD² \\ ${ }^{1}$ Department of Urology, Wonkwang University Sanbon Hospital, Wonkwang University College of Medicine, Gunpo, Korea \\ ${ }^{2}$ Urological Science Institute, Department of Urology, Yonsei University College of Medicine, Seoul, Korea
}

The prevalence of urolithiasis is increasing not only in South Korea but also around the world. Urolithiasis has a high recurrence rate, therefore, reducing it is very important in the quality of life for stone formers. For this purpose, dietary modifications and drug therapy can be performed through stone analysis and 24-hour urine collection. Stone analysis is recommended for all stone formers, and the 24-hour urine collection is usually recommended for recurrent stone formers or high-risk groups. A general dietary modification for all stone formers includes a sufficient fluid intake, low levels of sodium, sugar, and animal protein, a normal calcium diet, as well as a high amount of citrate intake. Drug therapy should be performed in cases such as the recurrence of stones or increase of the existing ones, even after the application of preservation therapy, such as dietary modification. The ideal drug therapy should prevent the occurrence of urolithiasis, have no side effects, and have a suitable patients' compliance. Follow-up should be performed periodically, through 24-hour urine collections and imaging studies. For follow-up imaging studies, a lowdose non-enhanced computed tomography is recommended, and it can be performed once a year if the patient is in a stable state. To control various and complex metabolic abnormalities in recurrent stone formers, multiple approaches may be required through diet modifications, drug therapy, treatment of the metabolic syndrome, and lifestyle modifications.

Key Words: Urolithiasis; Prevention; Diet therapy; Drug therapy

\section{서론}

요로결석은 한국에서 평생 유병률 $10 \%$ 정도로 발생하며, 매우 흔한 질환 중 하나이다. 비뇨의학과 장기별 질환 중 3 대

Received: September 25, 2020 Accepted: October 21, 2020

Corresponding author: Joo Yong Lee

E-mail: joouro@yuhs.ac

C) Korean Medical Association

This is an Open Access article distributed under the terms of the Creative Commons Attribution Non-Commercial License (http://creativecommons. org/licenses/by-nc/3.0) which permits unrestricted non-commercial use, distribution, and reproduction in any medium, provided the original work is properly cited.
질환에 속하는 높은 발생률 및 유병률을 보인다. 환경의 변 화로 인하여 국내뿐만 아니라 전 세계적으로 요로결석의 발 생률 및 유병률이 증가하는 추세이다[1]. 요로결석은 흔하게 재발하며, 치료 후 10 년 동안 절반 정도가 재발하고, $10 \%$ 에 서는 세 번 이상 재발하는 것으로 알려져 있다[2,3]. 요로결 석의 치료를 위하여 개인뿐만 아니라 사회의 직간접적인 비 용지출도 점점 상승하게 된다[4]. 요로결석 환자에게 있어서 재발을 예방하는 것은 요로결석을 치료하는 것과 더불어 환 자의 삶의 질의 향상과 사회경제적인 측면에 있어 매우 중요 하다 할 수 있다. 그리고 요로결석 환자 개개인에게 맞는 적 절한 예방과 관리를 위해서는 결석성분 분석 및 24 시간 요중 
Table 1. Stone classification by etiology

\begin{tabular}{ll}
\hline \multicolumn{1}{c}{ Etiology } & \multicolumn{1}{c}{ Stone composition } \\
\hline Non-infection stones & Calcium oxalate \\
& Calcium phosphate \\
& Uric acid \\
Infection stones & Struvite (magnesium ammonium phosphate) \\
& Carbonate apatite \\
& Ammonium urate \\
Genetic causes & Cystine \\
& Xanthine \\
Drug stones & 2,8-Dihydroxyadenine \\
\hline
\end{tabular}

결석관련위험인자 등의 대사 검사가 필수이다. 결석성분 분 석은 대개 적외선 분광법으로 시행되고 결석성분은 진단 및 치료 결정에 있어서 기초가 된다. 24시간 요중결석관련위 험인자 검사를 시행하기 위해서 환자는 정상적으로 일상적 인 식사를 하고, 최소 20 일 동안 요로결석이 없는 상태이어 야 한다. 이와 같이 지난 수십 년 동안 요로결석의 대사 이 상에 대한 연구들이 진행되었고, 여러가지 대사 이상을 통하 여 요로결석이 발생한다는 것은 잘 알려져 있다. 식이는 요 로결석의 성장에 관여하는 촉진 성분들과 억제제들의 요중 농도에 중요한 역할을 한다. 약물요법은 근본적인 대사 이상 을 교정하고 새로운 결석 형성을 억제하고, 약물요법 자체의 심각한 부작용이 없어야 한다. 식이요법 및 약물요법을 병행 하여도 요로결석은 재발할 수 있다. 따라서 대사 이상에 대 한 주기적인 혈액검사, 24 시간 요중결석관련위험인자 및 영 상검사 등을 통하여 추적관리를 받는 것이 필요하다. 이에 요로결석 환자의 재발을 막기 위한 예방과 관리에 대해 알 아보고자 한다.

\section{결석의 성분 분석}

결석성분 분석은 가능한 모든 요로결석 환자에서 시행하 는 것이 추천된다. 결석성분 분석은 진단과 치료 결정에 있 어 기반이 되는데 분석방법으로는 주로 적외선 분광법, $\mathrm{X}$ 선 회절법을 이용한다. 결석성분 분석은 결석이 재발할 때마다 시행하는 것이 추천된다. 특히 약물치료 중 재발, 결석을 완
전히 제거한 후 조기 재발, 장기간 결석이 없었던 경우의 재 발에서는 결석성분의 변화 가능성이 있기 때문에 결석성분 분석을 다시 하는 것이 중요하다[5,6]. 결석성분에는 많은 종 류들이 있으나 원인별로 감염 또는 비감염, 유전적 요인, 약 물결석 등으로 분류해 볼 수 있다. 원인에 따른 결석성분 분 류는 Table 1에서 정리하였다[7].

\section{1. 칼슘석}

칼슘석은 대략 요로결석의 $75 \%$ 를 차지하고 이 중 대부분 은 옥살산칼슘석(calcium oxalate stone)이며 인산칼슘석 (calcium phosphate stone)은 드물게 발생한다[8]. 옥살산칼 슘석은 연령과 성별을 통틀어 제일 흔한 결석이다[9]. 옥살산 칼슘석의 가장 흔한 대사 이상은 고칼슘뇨증이다. 고칼슘뇨 증은 성인 옥살산칼슘석의 원인 중 30-60\% 정도의 비율을 보이며, 고옥살산뇨증(26-67\%), 고요산뇨증(15-46\%), 저 마그네슘뇨증(7-23\%) 및 저구연산뇨증(5-29\%)이 흔한 대 사 이상증이다[10]. 인산칼슘석은 매우 높은 재발률을 가지 고 있다. 인산칼슘석은 탄산염인회석(carbonate apatite)과 브루사이트(brushite)로 나누어진다. 탄산염인회석은 요로감 염과 관련이 있으며, 요 $\mathrm{pH}>6.8$ 에서 결정화되며, 브루사이 트는 요 중 높은 칼슘과 요 중 높은 인산의 농도로 인하여 $\mathrm{pH}$ 6.5-6.8에서 결정화된다. 브루사이트는 요로감염과 관 련되어 있지 않다[11]. 브루사이트의 경우, 옥살산칼슘석으 로 시작하여 체외충격파쇄석술과 같은 시술로 인한 네프론의 손상으로 인하여 요산성화의 부전으로 인하여 발생한다는 가 설이 제시되었다[12]. 또한 인산칼슘석의 가장 많은 대사 이 상은 고칼슘뇨증으로, 재발방지 치료의 기본은 고칼슘뇨증과 동일하게 치료할 수 있음을 제시하고 있다[13]. 인산칼슘석의 가능한 원인으로 부갑상샘항진증, 신세관산증(renal tubular acidosis), 요로감염이 있고, 그에 따른 치료법을 요한다. 신 세관산증은 약물치료로 교정 가능하지만, 원발성 부갑상샘항 진증은 수술로만 치료될 수 있다.

\section{2. 요산석}

요산석(uric acid stone)은 매우 높은 재발률을 보이며, 요 로결석의 약 $10 \%$ 를 차지한다[14]. 그러나 한국에서 비율은 
Table 2. High risk factors of stone recurrence

\begin{tabular}{|c|c|}
\hline Etiology & Risk factor \\
\hline General factors & $\begin{array}{l}\text { Early onset of urolithiasis (especially children and } \\
\text { teenagers) } \\
\text { Familial stone formation } \\
\text { Brushite-containing stones } \\
\text { Uric acid and urate-containing stones } \\
\text { Infection stones }\end{array}$ \\
\hline Diseases & $\begin{array}{l}\text { Hyperparathyroidism } \\
\text { Metabolic syndrome } \\
\text { Nephrocalcinosis } \\
\text { Polycystic kidney disease } \\
\text { Gastrointestinal diseases (jejuno-ileal bypass, intestinal } \\
\text { resection, Crohn's disease, malabsorptive conditions, } \\
\text { enteric hyperoxaluria after urinary diversion) and } \\
\text { bariatric surgery }\end{array}$ \\
\hline Genetic causes & $\begin{array}{l}\text { Cystinuria (type } A, B \text {, and } A B \text { ) } \\
\text { Primary hyperoxaluria } \\
\text { Renal tubular acidosis type } 1 \\
\text { 2,8-Dihydroxyadeninuria } \\
\text { Xanthinuria } \\
\text { Lesch-Nyhan syndrome } \\
\text { Cystic fibrosis }\end{array}$ \\
\hline $\begin{array}{l}\text { Anatomical } \\
\text { abnormalities }\end{array}$ & $\begin{array}{l}\text { Medullary sponge kidney } \\
\text { Ureteropelvic junction obstruction } \\
\text { Calyceal diverticulum, calyceal cyst } \\
\text { Ureteral stricture } \\
\text { Vesico-uretero-renal reflux } \\
\text { Horseshoe kidney } \\
\text { Ureterocele }\end{array}$ \\
\hline $\begin{array}{l}\text { Environmental } \\
\text { factors }\end{array}$ & $\begin{array}{l}\text { High ambient temperatures } \\
\text { Chronic lead and cadmium exposure }\end{array}$ \\
\hline
\end{tabular}

더 높은 것으로 보고되었다[15,16]. 요산석 형성의 두 가지 주요한 요인은 고요산뇨증과 낮은 요 $\mathrm{pH}$ 이다. 원인으로는 과다한 식이섭취(동물성단백질), 통풍, 요산 배출 증가, 요 산 과다 생성, 만성설사, 당뇨 및 대사증후군등이 있다. 당뇨 및 대사증후군은 요 $\mathrm{pH}$ 감소와 관련이 있다. 그리고 비만일 수록 요 $\mathrm{pH}$ 는 더 낮아지고 요 중 요산 배출은 더 높아진다 [17]. 고요산뇨 옥살산칼슘석의 형성은 요 $\mathrm{pH}>5.5$ 에서 형 성이 되고, 요산석의 경우 요 $\mathrm{pH}<5.5$ 에서 형성되는 것으로 알려져 있다[18].

\section{3. 시스틴석}

시스틴석(cystine stone)은 모든 성인 결석의 1-2\%, 소아 결석의 6-8\%를 차지한다[19,20]. 시스틴석은 시스틴뇨증에 의해 드물게 발생하는 유전질환이다. 때로는 특이증상 없이 사슴뿔 결석 형태를 이루며, 소아청소년기에 첫 요로결석이
발생한 경우 시스틴석을 의심해 볼 수 있다. 비록 유전성 질 환이지만 시스틴뇨증 환자마다 그리고 환자의 일생에 걸쳐 요로결석 발생이 다양하므로 요로결석 형성에는 식이나 수 분섭취량 같은 명백한 요인들을 갖고 있다.

\section{4. 감염석}

감염석(stuvite)은 마그네슘, 암모늄, 인산으로 구성되어 있으며 전체 결석의 약 2-15\% 정도를 보이고 재발률이 높 다. 적절히 치료하지 않으면 사슴뿔 결석 형태로 발달할 수 있다. 요소분해 박테리아에 감염되면 요 중 요소가 분해되 면서 암모니아 생성 및 요 $\mathrm{pH}$ 가 증가하면서 인산의 용해도 가 떨어지게 되어 감염석이 새로이 형성되거나 기존 결석 이 자라게 된다[21]. 요소분해박테리아는 다양하게 있으나 장내 세균군에서 많고, 감염석과 가장 흔하게 연관된 균은 Proteus mirabilis이다[22].

\section{4시간 요중결석관련위험인자}

대사 이상 확인을 위해 혈액검사로는 혈중 크레아티닌, 나 트륨, 칼륨, 염소, 이온화 칼슘(또는 전체 칼슘 + 알부민), 요 산 등을 측정하고 혈중 칼슘수치가 증가된 경우에는 부갑상 선호르몬과 비타민 $\mathrm{D}$ 의 측정을 해야 한다. 24 시간 요중결석 관련위험인자 검사는 대개 결석재발 또는 고위험군에서 추 천된다. 이를 통해 소변량, 요 $\mathrm{pH}$, 비중, 칼슘, 옥살산, 요산, 구연산, 나트륨, 마그네슘 등을 측정한다. 24시간 요중결석 관련위험인자 검사를 할 때 환자는 일상적인 생활과 식사를 하여야 하고, 최소 20 일 동안 결석이 없는 상태여야 한다[6]. 별도로 검사를 두 번 시행하는 것이 더 정확한 결과가 나올 수 있어 추천된다. 요로결석 재발의 고위험군은 Table 2에 서 정리하였다[7].

\section{1. 고칼슘뇨증}

고칼슘뇨증은 특발성 고칼슘뇨증, 육아종성질환, 부갑상선 기능항진증, 비타민D 과다, 악성종양 등으로 발생할 수 있다. 특발성 고칼슘뇨증은 흡수성고칼슘뇨, 골흡수성고칼슘뇨, 
신성고칼슘뇨로 분류할 수 있다. 하지만 고칼슘뇨증 환자들 은 하나 이상의 이상소견을 보이고, 시간이 지남에 따라 분 류가 바뀔 수도 있어서 이러한 분류의 임상적 중요성은 불분 명하다. 따라서 임상적 목적으로 공복 및 칼슘부하 시험은 필수적이지 않다.

\section{2. 저구연산뇨증}

결석형성의 주요 억제물질이라고 생각되는 것이 구연산 이다. 요 중 구연산의 증가는 칼슘과 결합함으로써 칼슘석 형성을 낮출 수 있다. 저구연산뇨증은 만성설사, 특발성 또 는 대사성 산증이나 저칼륨혈증에 의해 발생할 수 있고 결석 환자에서 단독으로 또는 고칼슘뇨증, 고옥살산뇨증과 동반 되어 관찰될 수 있다. 요 중 구연산은 알칼리증에 의해 배출 이 증가하고 산증에 의해 배출이 감소한다.

\section{3. 원발성 고옥살산뇨증}

원발성 고옥살산뇨증(Type 1, Type 2)은 옥살산 합성에 대한 희귀한 상염색체 열성질환이다. 가장 흔한 Type 1은 간세포에서 alanine:glyoxylate aminotransferase (AGT) 효소의 결핍으로 글라이옥살산(glyoxylate) 대사가 손상되어 발생한다. AGT 효소의 결핍으로 인해 결과적으로 옥살산의 합성과 배출이 증가한다.

\section{4. 장인성 고옥살산뇨증}

장인성 고옥살산뇨증은 지방의 장내흡수장애로 인한 옥살 산의 흡수 증가로 인해 발생한다. 주로 장절제 이후, 흡수장 애성 비만수술, 크론씨병, 췌장부전 등에서 나타난다.

\section{5. 옥살산의 과도한 섭취}

옥살산이 함유된 음식을 과도하게 섭취하면 이차성 고옥살 산뇨증이 발생할 수 있다. 특히 저칼슘식이를 하는 경우, 옥 살산의 과도한 섭취는 결석 발생 가능성을 더 높일 수 있다.

\section{6. 고요산뇨증}

요산은 퓨린(purine)의 대사물질로, 요 중 요산배출의 증가 는 요산석과 옥살산칼슘석 형성을 증가 시킬 수 있다. 가장
주요한 원인은 퓨린의 과다 섭취이다. 그 외, 대사증후군, 통 풍, 만성설사, 염증성 장질환, 골수증식성 질환, 암환자, 용 혈성 빈혈, 회장루 환자에서 고요산뇨증이 나타날 수 있다.

\section{7. 저마그네슘뇨증}

마그네슘은 칼슘결석 저해제로 알려져 있다. 장내에서는 옥살산과 결합하여 옥살산의 흡수를 줄이고 소변에서는 요 중 옥살산과 결합하여 옥살산 칼슘석의 형성을 낮출 수 있 다. 저마그네슘뇨증은 적은 섭취량, 만성설사 등으로 기인 될 수 있는데, 저마그네슘뇨증 칼슘석 환자의 $65 \%$ 에서 저 구연산뇨증, $40 \%$ 에서 적은 소변량(하루 $1 \mathrm{~L}$ 미만) 이 동반 될 수 있다[23].

\section{8. 시스틴뇨증}

시스틴뇨증은 상염색체열성 질환으로, 시스틴에 대해 신 세뇨관에서의 재흡수 감소, 장에서의 흡수 감소로 소변에 축 적되어 시스틴석을 발생시킨다. 시스틴 용해도는 요 $\mathrm{pH}$ 에 영향을 많이 받는다. 알칼리뇨에서 최대 세 배까지 용해도가 증가하지만 요 $\mathrm{pH}$ 가 7 보다 클 경우에만 증가한다.

\section{식이요법을 통한 예방법}

요로결석의 발생에 있어 위험인자로는 유전적, 지리적, 직 업적, 해부학적 원인 등이 있으며, 식습관 역시 중요한 인자 이다. 식이는 요로결석의 형성과 성장에 영향을 주므로, 식 이조절을 통해 요로결석 발생을 예방할 수 있다. 요로결석 환자의 식습관 및 식이보충제에 대해 문의하고 파악을 해야 한다. 아래에서 결석 성분에 따른 식이요법에 대해 알아보도 록 하겠다. 일반적인 예방법에 대한 요약은 Table 3에서 정 리하였다[7].

\section{1. 칼슘석}

\section{1) 다량의 수분섭취}

모든 요로결석 환자들은 하루 최소 $2.0-2.5 \mathrm{~L}$ 의 소변량을 목표로, 또는 2.5-3 L의 수분섭취를 해야 한다. 하루 $2 \mathrm{~L}$ 이 
Table 3. General urolithiasis prevention

\begin{tabular}{ll}
\hline \multicolumn{1}{c}{ Method } & \multicolumn{1}{c}{ Detail } \\
\hline Fluid intake & Fluid amount: $2.5-3.0 \mathrm{~L} /$ day \\
& Circadian drinking \\
& Neutral pH beverages \\
& Diuresis: $2.0-2.5 \mathrm{~L} /$ day \\
Nutritional advice & Balanced diet \\
& Rich in vegetables and fiber \\
& Normal calcium content: $1-1.2 \mathrm{~g} /$ day \\
& Limited NaCl content: $4-5 \mathrm{~g} /$ day \\
& Limited animal protein content: $0.8-1.0 \mathrm{~g} / \mathrm{kg} /$ day
\end{tabular}

상의 소변량이 되도록 수분 섭취를 증가하였을 때 현저히 결 석 재발률이 낮았다( $12 \%$ vs. $27 \%, P=0.008)$ [24]. 다른 음 료로는 대개 저당류, 저칼로리, 무알코올 음료가 추천된다. 커피와 차는 옥살산을 많이 포함하고 있어 결석 형성을 증가 시킨다고 고려되어지지만 다량의 커피와 차는 결석 형성을 낮추는 효과가 있기도 했다[25]. 알코올은 결석 발생의 위험 을 증가시킬 수 있다. 하지만 맥주와 와인은 결석 발생의 위 험을 줄였다는 연구가 있었으며 설탕이 첨가된 음료들은 결 석 발생의 위험을 증가시킨다[25]. 요 중 구연산은 칼슘석 형 성을 억제하므로, 구연산을 함유하는 다양한 감귤류 주스들 의 복용이 추천된다. 오렌지주스는 요 중 구연산을 효과적으 로 증가시키고[26], 레모네이드와 라임주스는 연구에 따라 논란이 있다[27,28].

2) 염분 섭취 제한 및 정상 칼슘 섭취

저염식을 했을 때 고칼슘뇨증 결석 환자에서 칼슘뇨를 줄 일 수 있었다[29]. 정상칼슘식이는 장내에서 옥살산과 결합 하여 옥살산의 소변 배출을 낮춤으로써 결석 예방에 효과 가 있다. 저칼슘식이 $(400 \mathrm{mg} /$ day $)$ 와 정상칼슘식이(1,200 $\mathrm{mg} /$ day)의 결석 재발률을 비교한 연구에서 정상칼슘식 이군에서의 결석 재발률이 저칼슘식이군보다 $51 \%$ 낮았다 [29]. 칼슘보충제는 결석 환자에게 일반적으로 추천되지 않 는다. 칼슘석 환자가 칼슘보충제를 복용해야 한다면 24시 간 요중결석관련위험인자 검사를 시행해서 요 중 칼슘 농 도가 증가하면 칼슘보충제를 중단하는 것을 고려해야 한다. 또한 칼슘보충제를 식이와 함께 복용하는 것이 고칼슘뇨증 의 증가 위험이 없다는 연구도 있다[30]. 비타민D는 고칼슘 뇨증이나 결석 재발의 관련성에 대해 논란이 있다. 만약, 비
타민D 결핍증이 있는 옥살산칼슘석 환자에서 비타민D 보 충이 필요하다면, 고칼슘뇨증에 대해 주기적인 모니터링을 해야 한다.

\section{3) 옥살산 섭취 제한}

고옥살산뇨증은 유전적 원인인 일차성 고옥살산뇨증 외 에, 옥살산의 장내 흡수를 조절하는 성분의 섭취부족, 고옥 살산 성분의 과다섭취등으로 발생할 수 있는데, 요 중 옥살 산은 결석의 위험을 증가시킨다[31]. 따라서 칼슘석 환자들 은 옥살산이 풍부한 음식 섭취를 제한해야 한다. 많은 양의 옥살산이 포함되어 있는 음식으로는 시금치, 대황, 감자, 초 콜릿, 땅콩, 캐슈넛 및 아몬드 등이 있다. 고용량의 비타민C 는 요 중 옥살산 배설을 증가시켜 결석 생성의 위험을 증가 시킨다. 이에, 매일 $1,000 \mathrm{mg}$ 를 초과하는 비타민C 복용은 권장되지 않는다[32-34].

4) 과일과 채소 섭취의 권장 및 비유제품 동물성 단백질 의 제한

칼륨이 풍부한 식품, 특히 과일과 채소섭취는 칼슘석 형 성을 억제하는 요 중 구연산을 증가시킬 수 있다[35]. 동물 성 단백질의 섭취증가는 결석발생 증가와 관계가 있지만 식 물성 단백질 섭취는 결석발생 증가와 관련이 없다[36]. 동물 성 단백질 섭취와 관련하여 유제품인지 아니면 비유제품인 지에 따라 달라질 수 있다. 동물성 단백질(비유제품, 유제품 모두) 섭취가 많을수록 요 중 칼슘 배출량이 증가할 수 있으 나, 비유제품 동물성 단백질 섭취는 요 중 구연산을 낮추는 반면, 유제품 단백질의 섭취는 요 중 구연산 배설은 증가시 키고 요 중 옥살산 배설은 낮추었다[36]. 따라서 동물성 단백 질을 과다 섭취해서는 안되며 체중 $1 \mathrm{~kg}$ 당 $0.8-1.0 \mathrm{~g}$ 으로 제한해야 한다[37]. 칼슘석에 관한 식이요법에 대해 Table 4 와 Table 5 에서 요약하였다.

\section{2. 요산석}

\section{1) 수분 섭취와 요 알칼리화}

요산 결정의 형성과 성장은 산성화된 소변에서 일어난다 [38]. 따라서, 수분 섭취와 요 알칼리화가 요산석 예방의 주 요 방법이다. 요산석 예방을 위해 요 알칼리화는 6.0 이상의 요 $\mathrm{pH}$ 를 목표로 하고, 식이 조절이나 약물로 달성할 수 있다. 
Table 4. The diet for urolithiasis prevention (calcium oxalate stones)

\begin{tabular}{|c|c|c|}
\hline Stone type & & Diet modification \\
\hline \multirow[t]{10}{*}{ Calcium oxalate } & \multicolumn{2}{|c|}{$\begin{array}{l}\text { Limiting oxalate to less than } 50 \mathrm{mg} \text { a day ( } 2 \mathrm{mg} \text { or less of oxalate per } 100 \mathrm{mg} \text { of } \\
\text { food is low, } 2-10 \mathrm{mg} \text { is normal, and more than } 10 \mathrm{mg} \text { is high) }\end{array}$} \\
\hline & Grains & $\begin{array}{l}\text { Low: rice, bread, cream spaghetti, noodles, macaroni } \\
\text { Normal: cornbread, sponge cake, tomato sauce spaghetti } \\
\text { High: sweet potato, fruitcake, corn }\end{array}$ \\
\hline & Meat & $\begin{array}{l}\text { Low: egg, cheese, beef, lamb, pork, poultry, fish, shellfish } \\
\text { Normal: sardine } \\
\text { High: roast meat dish with tomato sauce }\end{array}$ \\
\hline & Vegetable & $\begin{array}{l}\text { Low: cabbage, cauliflower, radish, mushroom, onion, pea, potato } \\
\text { Normal: asparagus, broccoli, carrot, corn, cucumber, lettuce, peas } \\
\text { canned, tomato } \\
\text { High: spinach, mustard, celery, parsley, scallion, leek, eggplant, } \\
\text { lettuce, kale, pumpkin }\end{array}$ \\
\hline & Fats and oils & $\begin{array}{l}\text { Low: bacon, mayonnaise, salad dressing, vegetable oil, butter, } \\
\text { margarine } \\
\text { High: nuts (peanuts, walnuts, almonds, pine nuts), peanut butter, } \\
\text { cashew nuts }\end{array}$ \\
\hline & Milk & Low: buttermilk, low-fat milk, skimmed milk, yogurt with low oxalate \\
\hline & Fruits & $\begin{array}{l}\text { Low: apple juice, avocado, banana, grapefruit, green grape, mango, } \\
\text { melon, watermelon, grape, peach, lemon }\end{array}$ \\
\hline & & $\begin{array}{l}\text { Normal: apple, raisin, cherry, cranberry, orange, peach, pear, } \\
\text { pineapple, plum }\end{array}$ \\
\hline & & $\begin{array}{l}\text { High: blackberry, blueberry, fruit cocktail, grape, orange peel, } \\
\text { strawberry, tangerine }\end{array}$ \\
\hline & Etc. & $\begin{array}{l}\text { Low: bottled beer, cola, whiskey, wine, coconut, salt, pepper, sugar } \\
\text { High: draft beer, tea, cocoa, chocolate }\end{array}$ \\
\hline
\end{tabular}

Table 5. The diet for urolithiasis prevention (calcium phosphate stones)

\begin{tabular}{|c|c|c|}
\hline Stone type & & Diet modification \\
\hline \multirow{8}{*}{$\begin{array}{l}\text { Calcium } \\
\text { phosphate }\end{array}$} & \multicolumn{2}{|c|}{ Limiting foods with high phosphorus content (below) } \\
\hline & Grains & $\begin{array}{l}\text { Mixed grain rice, millet, brown rice, adlay, sorghum, red bean, chestnut, ginko, } \\
\text { buckwheat noodles, corn, potato, sweet potato, black bean, yellow bean }\end{array}$ \\
\hline & Meat & Ham, canned fish, dried fish, clam meat, fishcake \\
\hline & Vegetables & Kamchatka goatsbeard, dried radish, young radish \\
\hline & $\begin{array}{l}\text { Fats and } \\
\text { oils }\end{array}$ & $\begin{array}{l}\text { Pumpkin seeds, sunflower seeds, pine nuts, walnuts, peanuts, almonds, } \\
\text { peanut butter }\end{array}$ \\
\hline & Milk & Milk, yogurt, ice cream, cheese \\
\hline & Fruits & Raisins \\
\hline & Etc. & Chocolate, instant coffee, royal jelly \\
\hline
\end{tabular}

이에, 요산석을 예방하기 위해 하루 2.5-3 L의 수분섭취가 추천되고[39], 오렌지 또는 레모네이드 주스는 요 알칼리화 및 소변량 증가에 도움이 된다[28].

2) 비유제품 동물성 단백질의 섭취제한

채식을 더 많이 하고 동물성 단백질 섭취를 줄이면 요 $\mathrm{pH}$ 가 증가하고 요산 배설을 줄일 수 있다. 대부분의 과일과 채 틴석에 관한 식이요법에 대해 Table 7에서 요약하였다.

소는 신장 알칼리 부하를 주고, 육류, 어 류, 해산물, 가금류, 치즈, 달걀, 곡물은 모두 신장 산 부하를 주는 반면, 우유와 요구르트는 산 중성이다[40]. 요산은 퓨 린 대사의 최종 산물로, 고요산뇨증 환 자는 퓨린 함량이 많은 음식을 제한해야 한다. 퓨린 함량이 많은 음식에는 멸치, 정어리, 청어, 고등어, 가리비, 홍합, 동 물내장, 조개류, 양고기, 소고기, 돼지고 기, 가금류 등이 있다[41,42]. 요산석에 관한 식이요법에 대해 Table 6에서 요약 하였다.

\section{3. 시스틴석}

1) 수분섭취

시스틴석 환자에게 충분한 수분섭취 는 매우 중요하다. 낮은 요 중 시스틴 농 도를 유지하기 위해 하루에 최소 4-5 L 의 수분을 섭취해야 한다[43]. 하루 중 고르게 분배하여 수분을 섭취하는 것이 필요하다.

2) 염분 및 동물성 단백질 섭취 제한 염분섭취량이 낮을수록 요 중 시스틴 농도가 감소하므로 염분 제한을 해야 한 다[44-46]. 동물성 식품에는 시스틴과 메티오닌(시스틴으로 대사)이 풍부하므 로 동물성 단백질 섭취를 제한해야 한다. 그러나, 메티오닌은 성장에 필수적인 아 미노산이므로 성장기 아이들에게는 메티 오닌 섭취 제한에 주의하여야 한다. 시스

\section{약물요법을 통한 요로결석의 예방}

요로결석의 약물치료는 재발성 결석의 고위험 환자에서 
Table 6. The diet for urolithiasis prevention (uric acid stones)

\begin{tabular}{|c|c|c|}
\hline Stone type & & Diet modification \\
\hline \multirow[t]{13}{*}{ Uric acid } & \multicolumn{2}{|c|}{$\begin{array}{l}\text { Limiting foods high in purine and recommending the intake of alkaline foods } \\
\text { (15 mg or less of purine per } 10 \text { omg of food is low, } 50-150 \mathrm{mg} \text { is normal, and } \\
150-180 \mathrm{mg} \text { is high) }\end{array}$} \\
\hline & \multirow[t]{2}{*}{ Grains } & Low: rice, barley, flour, cookies, bread, noodles, corn, sugar \\
\hline & & $\begin{array}{l}\text { Normal: whole grains (oatmeal, prosomillett, quinoa, brown rice, } \\
\text { buckwheat, whole wheat, mung bean) }\end{array}$ \\
\hline & \multirow[t]{3}{*}{ Meat } & Low: egg, cheese, tofu \\
\hline & & $\begin{array}{l}\text { Normal: beef, pork, chicken, ham, bacon, crab, mackerel, bluefin, } \\
\text { shellfish }\end{array}$ \\
\hline & & $\begin{array}{l}\text { High: organ meat, herring, mackerel, anchovy, sardine, dried squid, } \\
\text { scallop, fish eggs, meat soup, goose }\end{array}$ \\
\hline & \multirow[t]{2}{*}{ Vegetable } & Low: any food other than restricted food \\
\hline & & $\begin{array}{l}\text { Normal: asparagus, bean sprout, mushroom, bean, spinach, } \\
\text { cauliflower }\end{array}$ \\
\hline & Fats and oils & Low: any food other than restricted food \\
\hline & Milk & Low: milk, ice cream, yogurt \\
\hline & Fruits & Low: fresh fruit, fruit juice \\
\hline & \multirow[t]{2}{*}{ Etc. } & Low: soda, coffee, tea \\
\hline & & Normal: yeast, soju, beer, rice wine, wine, whiskey \\
\hline
\end{tabular}

Table 7. The diet for urolithiasis prevention (cystine stones)

\begin{tabular}{|c|c|c|}
\hline Stone type & & Diet modification \\
\hline \multirow[t]{3}{*}{ Cystine } & \multicolumn{2}{|c|}{ Low-protein meals are helpful, and an alkaline food intake is recommended } \\
\hline & $\begin{array}{l}\text { Alkaline } \\
\text { food }\end{array}$ & $\begin{array}{l}\text { Barley rice, brown rice, corn, potato, taro, red beans, tofu, soybeans paste, } \\
\text { egg white, kimchi, seaweed, kelp, spinach, carrot, pumpkin, cucumber, } \\
\text { eggplant, onion, cabbage, radish, lettuce, mushrooms, bamboo shoots, } \\
\text { tomato, watermelon, grapes, raisins, banana, strawberry }\end{array}$ \\
\hline & Acid food & $\begin{array}{l}\text { Polished rice, flour food, bread, buckwheat noodles, asparagus, peas, peanuts, } \\
\text { egg yolk, chicken, pork, beef, squid, eel, loach, abalone, shrimp, carp, sea } \\
\text { bream, butter, cheese, salad oil, fried food, alcoholic beverages (except for } \\
\text { wine), cocoa, coke, spice, vinegar }\end{array}$ \\
\hline
\end{tabular}

는 식이요법과 병행하는 필수적 치료법이다. 이를 위해 결 석성분 분석 및 24 시간 요중결석관련위험인자 검사를 시 행해야 한다. 이상적인 약물치료는 결석발생이 중지되고, 부작용이 없어야 하며, 환자의 약물요법 순응도가 높아야 한다. 현재까지 제시되고 있는 약물들의 효과에 대한 요약 은 Table 8에서 정리하였다[7]. 그러나, 24시간 요중결석관 련위험인자 검사가 한국에서 결석 치료의 보편적인 진단검 사로 진행되지 않기 때문에, 약물치료 시작 전 적절한 대사 이상을 확인하는 것이 중요하다. 특히, 재발성 옥살산칼슘 석과 같은 경우, 예방을 목표로 약물치료를 시행하기 전에 24 시간 요중결석 관련위험인자 검사는 반드시 시행하여야 한다[47,48].

\section{1. 옥살산칼슘석}

\section{1) Thiazide 이뇨제}

Thiazide 이뇨제는 요 중 칼슘배출을 낮출 수 있어 고칼슘뇨증 환자에서 처방 되어질 수 있다. Thiazide 이뇨제에 관 한 메타분석에서 보면, 요로결석 재발을 의미있게 감소시켰다(비교위험도 0.52 , 95\% 신뢰구간 0.39-0.69)[49]. 그리고 염분섭취제한을 같이 시행하여야 최대 한의 요 중 칼슘배출 저하 효과를 낼 수 있다. Thiazide 이뇨제 복용 시 저칼륨 혈증을 예방하기 위해 구연산 칼륨을 같 이 복용할 수 있다.

\section{2) 구연산 칼륨, 중탄산염나트륨}

Thiazide 이뇨제로 요 중 칼슘배출 저 하에 효과가 없거나, 부작용으로 복용 하지 못하는 경우, 구연산 칼륨이나 중 탄산염나트륨을 복용할 수 있다. 구연 산 칼륨과 중탄산염나트륨은 요 중 칼 슘배출 저하에 효과가 있다[50-52]. 또 한, 요 $\mathrm{pH}$ 를 6 이상 높여서 불용성의 요 산을 수용성으로 변환시켜 옥살산칼슘 석 형성을 낮출 수 있다. 저구연산뇨증 의 경우, 구연산 칼륨을 복용하면 요 중 구연산 배출이 증가하게 되어 결석 발생률을 낮출 수 있다 [53]. 구연산 칼륨에 대한 메타분석에서도 대조군에 비해 구 연산 칼륨은 유의하게 결석 발생률을 낮추었다[49].

3) 알로퓨리놀

알로퓨리놀(allopurinol)은 고요산뇨증이면서 정상 요 칼 슘 수치를 보이는 옥살산칼슘석 환자에서 결석 재발을 낮출 수 있었다[54,55].

\section{4) 피리독신}

Type 1 원발성 고옥살산뇨증 환자의 약 $1 / 3$ 에서 피리독신 (pyridoxine) 치료는 소변으로 옥살산 배출을 낮출 수 있다.

5) 칼슘제

장인성 고옥살산뇨증의 경우 장내 옥살산칼슘 복합체 형 
Table 8. Drug therapy that can be prescribed for urolithiasis in Korea

\begin{tabular}{|c|c|c|c|c|c|}
\hline Agent & Product & Dose & Efficacy & Side effect & Stone type \\
\hline Potassium citrate & Urocitra SR 1,080 mg & 2T BID/TID (20 mgEq BID/TID) & Urine alkalinization & $\begin{array}{l}\text { Hyperkalemia } \\
\text { Dyspepsia }\end{array}$ & $\begin{array}{l}\text { Calcium oxalate } \\
\text { Uric acid } \\
\text { Cystine }\end{array}$ \\
\hline Sodium bicarbonate & Tasna 500 mg & $\begin{array}{l}2 T \text { QID } \\
3 T \text { TID }\end{array}$ & - & - & $\begin{array}{l}\text { Calcium oxalate } \\
\text { Uric acid } \\
\text { Cystine }\end{array}$ \\
\hline Allopurinol & Zyroric 100 mg & 1-3T/day & $\begin{array}{l}\text { Treatment of } \\
\text { hyperuricosuria }\end{array}$ & $\begin{array}{l}\text { Skin lesion } \\
\text { Myalgia }\end{array}$ & $\begin{array}{l}\text { Calcium oxalate } \\
\text { Uric acid }\end{array}$ \\
\hline Thiazide & Dichlozid $25 \mathrm{mg}$ & $1 \mathrm{~T} \mathrm{BID}$ & - & $\begin{array}{l}\text { Hypotension } \\
\text { Diabetes }\end{array}$ & $\begin{array}{l}\text { Calcium oxalate } \\
\text { Calcium phosphate }\end{array}$ \\
\hline Calcium & - & 1,000 mg/day & - & - & Calcium oxalate \\
\hline Magnesium & - & 200-400 mg/day & - & Diarrhea & Calcium oxalate \\
\hline Pyridoxine & Plidoxine 50 mg & 2T/day & - & Multiple neuropathy & Calcium oxalate \\
\hline Febuxostat & Feburic 40/80 mg & $\begin{array}{l}80 \mathrm{mg} \\
1 \mathrm{~T}-3 \mathrm{~T} / \mathrm{day}\end{array}$ & - & - & $\begin{array}{l}\text { Calcium oxalate } \\
\text { Uric acid }\end{array}$ \\
\hline L-methionine & - & 600-1,500 mg/day & Urine pH 5.8-6.2 & - & $\begin{array}{l}\text { Infection stones } \\
\text { Calcium phosphate }\end{array}$ \\
\hline D-penicillamine & Artamin $250 \mathrm{mg}$ & $1 \mathrm{~T}$ & - & $\begin{array}{l}\text { Nephrotic syndrome } \\
\text { Dermatitis } \\
\text { Pancytopenia }\end{array}$ & Cystine \\
\hline Captopril & - & $25 \mathrm{mg}$ TID & - & $\begin{array}{l}\text { Skin lesion } \\
\text { Cough } \\
\text { Hypotension }\end{array}$ & Cystine \\
\hline
\end{tabular}

T, tablet; BID, bis in die (twice a day); TID, ter in die (three times a day); QID, quarter in die (four times a day).

성을 위해 음식섭취시 칼슘제( $1-4 \mathrm{~g} / \mathrm{day})$ 를 복용하면 요 중 옥살산 배출을 낮출 수 있다.

6) 마그네슘제제

요 중 마그네슘 배출을 증가시키기 위해 산화마그네슘 (magnesium oxide), 수산화마그네슘(magnesium hydroxide) 등이 사용되어질 수 있다. 하지만, 흡수율이 낮은 단점 이 있고 효과에 대해서는 논란이 있다. 위장장애(설사)가 주 요 부작용이다.

요 대사검사의 참고범위 및 대사 이상에 따른 옥살산칼슘 석의 약물치료는 Table 9에서 정리하였다[56,57].

\section{2. 인산칼슘석}

탄산염인회석은 고칼슘뇨증인 경우는 thiazide 이뇨제로 치료하고, 요 $\mathrm{pH}$ 가 6.5-6.8 이상인 경우, 요 $\mathrm{pH}$ 5.8-6.2 사이 유지를 목표로 L-메티오닌(methionine)을 복용한다. 이때 전신적인 산증에 대해 주의해야 한다.

\section{3. 요산석}

요산석의 약물치료는 요산의 요중 용해도를 높일 수 있는 약물을 통하여 요 $\mathrm{pH}$ 를 높이는 치료와 통풍 및 고요산혈증을 낮추는 치료로 나눌 수 있다[58]. 요산석의 예방적 치료는 요 $\mathrm{pH}$ 6.2-6.8이 목표치이며, 결석 용해 치료는 요 $\mathrm{pH}$ 6.5-7.2 가 목표치이다. 요 $\mathrm{pH}$ 가 7.2 이상으로 높아질 경우 인산칼슘 석이 발생할 가능성이 있으므로 주의해야 한다. 대부분의 요 산석 환자들은 위험요소로 고요산뇨증보다 낮은 요 $\mathrm{pH}$ 가 중 요하다고 알려져 있다[59]. 따라서 구연산 칼륨이나 중탄산염 나트륨은 요 $\mathrm{pH}$ 를 높임으로써 기존의 요산석뿐만 아니라 새 로운 요산석의 형성을 예방할 수 있는 우선적인 치료법이다. 요산저하제(allopurinol)는 요 알칼리화가 잘 되지 않거나(염 증성 장질환, 만성설사, 회장루환자), 요 알칼리화는 적절히 되었지만 요산석이 지속 발생하는 경우 고려되어진다.

\section{4. 시스틴석}

구연산 칼륨이나 중탄산염나트륨을 투여하여, 요 $\mathrm{pH}$ 를 
Table 9. Drug therapy for preventing calcium oxalate stones

\begin{tabular}{|c|c|c|c|}
\hline $\begin{array}{c}\text { Metabolic } \\
\text { abnormalities }\end{array}$ & Drug therapy & $\begin{array}{l}\text { 24-Hour urine } \\
\text { collection }\end{array}$ & Reference range \\
\hline Hypercalciuria & $\begin{array}{l}\text { Urocitra SR 1,080 mg 2T BID/TID } \\
\text { Tasna } 500 \text { mg 2T QID or 3T TID }\end{array}$ & Calcium & $\begin{array}{l}<300 \mathrm{mg} \text { (male) } \\
<250 \mathrm{mg} \text { (female) }\end{array}$ \\
\hline Hypocitraturia & Urocitra SR 1,080 mg 2T BID/TID & Citrate & $>320 \mathrm{mg}$ \\
\hline Hyperoxaluria & $\begin{array}{l}\text { Enteric: calcium } 1,000 \mathrm{mg} \text { and } \\
\text { magnesium } 200-400 \mathrm{mg} / \mathrm{day} \\
\text { Primary: pyridoxine } 5 \mathrm{mg} / \mathrm{kg} \rightarrow 20 \mathrm{mg} / \mathrm{kg}\end{array}$ & Oxalate & $<45 \mathrm{mg}$ \\
\hline Hyperuricosuria & $\begin{array}{l}\text { Urocitra SR 1,080 mg 2T BID/TID } \\
\text { Tasna } 500 \mathrm{mg} 2 \mathrm{~T} \text { QID or } 3 T \text { TID } \\
\text { Zyroric } 100 \mathrm{mg} 1-3 \mathrm{~T} / \text { day }\end{array}$ & Uric acid & $\begin{array}{l}<800 \mathrm{mg} \text { (male) } \\
<750 \mathrm{mg} \text { (female) }\end{array}$ \\
\hline Hypomagnesuria & Magnesium 200-400 mg/day & Magnesium & $50-150 \mathrm{mg}$ \\
\hline
\end{tabular}

T, tablet; BID, bis in die (twice a day); TID, ter in die (three times a day); QID, quarter in die (four times a day).
할 수 있어 여러 항생제와 시너지 효과 를 낼 수 있다. AHA는 요소세균에 감염 된 환자에서 단기간에 감염석의 성장을 효과적으로 억제할 수 있지만 부작용(심 각한 신경계, 혈액계, 피부 부작용)의 유 병률이 높다.

\section{생활양식 교정 및 대사증후군의 치료}

7.5-8.5로 유지한다. 충분한 수분섭취와 요 알칼리화에도 시스틴석이 재발이 지속된다면 티오프로닌(tiopronin)을 사 용해 볼 수 있다[60]. 티오프로닌은 불용성 형태의 시스틴 배출을 감소시킬 수 있고, 지속적인 시스틴석 생성시 사용 할 수 있겠으나 다양한 부작용(알러지, 발열, 발진, 메스꺼 움, 구토, 설사, 빈혈, 혈소판 및 백혈구 감소증, 신증후군 의 진행, 다양한 자가면역질환 등)으로 유지하기 어려운 경 우가 종종 있다.

\section{5. 감염석}

1) 항생제

감염이 있는 경우에는 $61.5 \%$ 에서 요로결석의 성장이 보 였고, 무균 소변 환자에서는 단지 $12.5 \%$ 에서만 결석 성장 을 보여 준 연구가 있었다[61]. 이 연구는 감염석 진행을 예 방하기 위해 요로감염을 치료해야 하는 필요성을 보여준다.

\section{2) 소변 산성화}

요소 분해 결과 발생하는 $\mathrm{pH}>7.2$ 의 알칼리 소변은 감염 석이 생성되는 조건이 된다. 그러므로, 감염석 성장을 억제 하기 위해 소변 산성화가 필요하다. $\mathrm{L}-$ 메티오닌은 감염석 의 용해를 위한 충분한 소변 산성화를 유발할 수 있다[62].

\section{3) 요소분해효소억제}

Acetohydroxamic acid (AHA)는 미국 식품의약국 승인을 받은 유일한 요소분해효소 억제제이며 세균성 요소분해효소 를 비가역적으로 억제하는 가장 널리 사용되는 경구약물이 다[63]. AHA는 신장청소율이 높고 박테리아 세포벽을 관통
비만과 당뇨는 대규모 코호트 연구에서 새로운 신장결석 형성과 관련이 있었다[64]. 비만은 요 $\mathrm{pH}$ 를 낮추고 요 중 칼 슘, 요 중 요산 배설을 증가시킨다[65-67]. 그리고 대사증후 군 중 신장결석 발생과 가장 밀접한 것은 고혈압이었다[68]. 따라서 식이요법, 약물요법과 더불어 대사증후군에 대한 치 료 및 관리가 필요하다,

\section{추적관리}

\section{1. 대사검사}

식이요법과 약물요법을 시작한 후, 24 시간 요중결석관련위 험인자 검사를 8-12주째 시행한다. 요중결석관련위험인자들 이 지속 이상 소견을 보이면, 약물의 용량 조절 후에 검사를 추가로 다시 시행한다. 요중결석관련위험인자들이 정상화 된 후에는, 검사는 1 년에 한 번 시행으로 충분할 수 있다.

\section{2. 영상검사}

결석의 성장이나 재발 여부를 확인하기 위해 영상의학적 검사를 주기적으로 시행해야 한다. 단순요로촬영, 초음파, 비조영증강 컴퓨터단층촬영(computed tomography, CT) 등으로 추적관리할 수 있는데 가장 정확한 검사법은 비조영 증강 CT이다. 비조영증강 CT는 많은 연구들에서 $95 \%$ 이상 의 민감도와 특이도를 보였다[69]. 비조영증강 CT는 요로결 석의 크기, 모양, 개수 및 위치에 대해 명확한 정보를 제공할 
수 있다. 최근에는 저선량비조영증강 CT로 방사선 노출을 감소시킬 수 있게 되었다[70]. 따라서 추적관리 시에 영상검 사로는 저선량비조영증강 CT가 추천되고 환자가 안정된 상 태이면 1 년에 한 번 시행으로 가능하다. 단순요로촬영은 칼 슘석과 같은 경우에 방사선비투과성으로 쉽게 진단될 수 있 으나, 요산석의 경우 방사선투과성으로 단순요로촬영에서는 발견하기 힘들 수 있다. 그리고 단순요로촬영으로는 석회화 된 장간막 림프절, 담석, 정맥결석 등을 요로결석으로 잘못 진단할 수 있다. 하지만 단순요로촬영은 이미 진단된 방사선 비투과성의 요로결석 환자의 경과를 추적할 때에는 유용할 수 있다. 정맥요로조영술은 비조영증강 CT가 나오기 전까지 요로결석의 진단을 위한 표준 검사법이었으나 현재는 제한 된 역할을 한다. 정맥요로조영술은 복부 초음파 및 단순요로 촬영 보다는 신장결석 진단에 있어 더 높은 민감도(64-87\%) 및 특이도(92-94\%)를 보인다[71]. 초음파는 현재 요로결석 진단에 제한적으로 사용된다. 다만, 방사선 촬영을 할 수 없 는 임산부, 소아 환자, 방사성투과성 결석 환자는 초음파로 추적관리할 수 있다.

\section{결론}

요로결석의 발생률 및 유병률은 증가하고 있으며 재발률 도 높은 질환으로 요로결석 환자들은 경제적 손실 및 삶의 질이 저하될 수 있다. 하지만 그동안 요로결석의 병태생리 및 대사 이상에 관한 많은 연구의 발전으로 요로결석은 식이 요법과 약물요법으로 예방과 관리가 가능할 수 있는 질환이 되었다. 이를 위해 요로결석 환자들은 결석성분 분석과 24시 간 요중결석관련위험인자 검사를 시행하여 그 결과에 맞는 적절한 식이요법과 약물요법을 시행하는 것이 필요하다. 그 리고 재발성 요로결석 환자에서 다양하고 복합적인 대사 이 상을 조절하기 위해서는 식이요법, 약물요법, 그리고 대사 증후군의 치료 및 생활양식 교정을 통한 다중 접근을 필요 로 할 수 있다. 식이요법은 각각의 결석 성분 및 대사 이상에 따르지만 일반적인 원칙으로는 충분한 수분섭취, 저염식이, 동물성 단백질의 섭취제한 등이 있다. 이상적인 약물요법은
요로결석의 발생이 억제되고, 부작용이 없어야 하며, 환자의 약물요법에 대한 순응도가 높아야 한다. 식이요법과 약물요 법을 시작한 이후에는 24 시간 요중결석관련위험인자 검사 및 영상 검사로 주기적인 추적관찰을 해야 한다.

\section{찾아보기말: 요로결석증; 예방; 식이요법; 약물요법}

\section{ORCID}

Hae Do Jung, https://orcid.org/0000-0002-8287-585X

Joo Yong Lee, https://orcid.org/0000-0002-3470-1767

\section{Conflict of Interest}

No potential conflict of interest relevant to this article was reported.

\section{References}

1. Tae BS, Balpukov U, Cho SY, Jeong CW. Eleven-year cumulative incidence and estimated lifetime prevalence of urolithiasis in korea: a national health insurance service-national sample cohort based study. J Korean Med Sci 2018;33:e13.

2. Strohmaier WL. Course of calcium stone disease without treatment. What can we expect? Eur Urol 2000;37:339-344.

3. Uribarri J, Oh MS, Carroll HJ. The first kidney stone. Ann Intern Med 1989;111:1006-1009.

4. Saigal CS, Joyce G, Timilsina AR; Urologic Diseases in America Project. Direct and indirect costs of nephrolithiasis in an employed population: opportunity for disease management? Kidney Int 2005;68:1808-1814.

5. Pearle MS, Asplin JR, Coe FL, Rodgers A, Worcester EM. Medical management of urolithiasis. In: Proceedings of the 2nd International Consultation on Stone Disease; 2007 Sep 5; Paris, France. Paris: Health Publications; 2008. p. 57-84.

6. Norman RW, Bath SS, Robertson WG, Peacock M. When should patients with symptomatic urinary stone disease be evaluated metabolically? J Urol 1984;132:1137-1139.

7. Turk C, Skolarikos A, Neisius A, Petrik A, Seitz C, Thomas K. EAU guidelines on urolithiasis 2019. Arnhem: European Association of Urology; 2019.

8. Scales CD Jr, Smith AC, Hanley JM, Saigal CS; Urologic Diseases in America Project. Prevalence of kidney stones in the United States. Eur Urol 2012;62:160-165.

9. Lieske JC, Rule AD, Krambeck AE, Williams JC, Bergstralh EJ, Mehta RA, Moyer TP. Stone composition as a function of age and sex. Clin J Am Soc Nephrol 2014;9:2141-2146.

10. Worcester EM, Coe FL. New insights into the pathogenesis of 
idiopathic hypercalciuria. Semin Nephrol 2008;28:120-132.

11. Fann CY, Huang PC, Yen AM, Chen HH. Patient utility measurement for managing ureteral stones: a modified standard gamble approach. Value Health Reg Issues 2012;1:87-92.

12.Krambeck AE, Handa SE, Evan AP, Lingeman JE. Brushite stone disease as a consequence of lithotripsy? Urol Res 2010; 38:293-299.

13. Krambeck AE, Handa SE, Evan AP, Lingeman JE. Profile of the brushite stone former. J Urol 2010;184:1367-1371.

14.Shekarriz B, Stoller ML. Uric acid nephrolithiasis: current concepts and controversies. J Urol 2002;168:1307-1314.

15.Kim JC, Cho KS, Kim DK, Chung DY, Jung HD, Lee JY. Predictors of uric acid stones: mean stone density, stone heterogeneity index, and variation coefficient of stone density by single-energy non-contrast computed tomography and urinary pH. J Clin Med 2019;8:243.

16.Lee JS, Cho KS, Lee SH, Yoon YE, Kang DH, Jeong WS, Jung HD, Kwon JK, Lee JY. Stone heterogeneity index on singleenergy noncontrast computed tomography can be a positive predictor of urinary stone composition. PLoS One 2018;13: e0193945.

17. Maalouf NM, Sakhaee K, Parks JH, Coe FL, Adams-Huet $\mathrm{B}$, Pak CY. Association of urinary $\mathrm{pH}$ with body weight in nephrolithiasis. Kidney Int 2004;65:1422-1425.

18.Pak CY, Sakhaee K, Fuller C. Successful management of uric acid nephrolithiasis with potassium citrate. Kidney Int 1986;30: 422-428.

19.Leusmann DB, Blaschke R, Schmandt W. Results of 5,035 stone analyses: a contribution to epidemiology of urinary stone disease. Scand J Urol Nephrol 1990;24:205-210.

20. Milliner DS, Murphy ME. Urolithiasis in pediatric patients. Mayo Clin Proc 1993;68:241-248.

21.Kramer G, Klingler HC, Steiner GE. Role of bacteria in the development of kidney stones. Curr Opin Urol 2000;10:35-38.

22.Silverman DE, Stamey TA. Management of infection stones: the Stanford experience. Medicine (Baltimore) 1983;62:44-51.

23.Preminger GM, Baker S, Peterson R, Poindexter J, Pak CY. Hypomagnesiuric hypocitraturia: an apparent new entity for calcium nephrolithiasis. J Lithotripsy Stone Dis 1989;1:22-25.

24. Borghi L, Meschi T, Amato F, Briganti A, Novarini A, Giannini A. Urinary volume, water and recurrences in idiopathic calcium nephrolithiasis: a 5-year randomized prospective study. J Urol 1996;155:839-843.

25. Ferraro PM, Taylor EN, Gambaro G, Curhan GC. Soda and other beverages and the risk of kidney stones. Clin J Am Soc Nephrol 2013;8:1389-1395.

26. Odvina CV. Comparative value of orange juice versus lemonade in reducing stone-forming risk. Clin J Am Soc Nephrol 2006;1: 1269-1274.

27. Koff SG, Paquette EL, Cullen J, Gancarczyk KK, Tucciarone PR, Schenkman NS. Comparison between lemonade and potassium citrate and impact on urine $\mathrm{pH}$ and 24-hour urine parameters in patients with kidney stone formation. Urology 2007;69:10131016.
28. Tosukhowong P, Yachantha C, Sasivongsbhakdi T, Ratchanon S, Chaisawasdi S, Boonla C, Tungsanga K. Citraturic, alkalinizing and antioxidative effects of limeade-based regimen in nephrolithiasis patients. Urol Res 2008;36:149-155.

29. Borghi L, Schianchi T, Meschi T, Guerra A, Allegri F, Maggiore $\mathrm{U}$, Novarini A. Comparison of two diets for the prevention of recurrent stones in idiopathic hypercalciuria. N Engl J Med 2002;346:77-84.

30.Penniston KL, Nakada SY. Effect of dietary changes on urinary oxalate excretion and calcium oxalate supersaturation in patients with hyperoxaluric stone formation. Urology 2009;73: 484-489.

31.Curhan GC, Taylor EN. 24-h uric acid excretion and the risk of kidney stones. Kidney Int 2008;73:489-496.

32. Massey LK, Liebman M, Kynast-Gales SA. Ascorbate increases human oxaluria and kidney stone risk. J Nutr 2005;135:16731677.

33. Taylor EN, Stampfer MJ, Curhan GC. Dietary factors and the risk of incident kidney stones in men: new insights after 14 years of follow-up. J Am Soc Nephrol 2004;15:3225-3232.

34. Traxer O, Huet B, Poindexter J, Pak CY, Pearle MS. Effect of ascorbic acid consumption on urinary stone risk factors. J Urol 2003;170:397-401.

35.Meschi T, Maggiore U, Fiaccadori E, Schianchi T, Bosi S, Adorni G, Ridolo E, Guerra A, Allegri F, Novarini A, Borghi L. The effect of fruits and vegetables on urinary stone risk factors. Kidney Int 2004;66:2402-2410.

36. Ferraro PM, Mandel EI, Curhan GC, Gambaro G, Taylor EN. Dietary protein and potassium, diet-dependent net acid load, and risk of incident kidney stones. Clin J Am Soc Nephrol 2016;11:1834-1844.

37. Fink HA, Akornor JW, Garimella PS, MacDonald R, Cutting A, Rutks IR, Monga M, Wilt TJ. Diet, fluid, or supplements for secondary prevention of nephrolithiasis: a systematic review and meta-analysis of randomized trials. Eur Urol 2009;56:72-80.

38. Bobulescu IA, Moe OW. Renal transport of uric acid: evolving concepts and uncertainties. Adv Chronic Kidney Dis 2012;19: 358-371.

39. Heilberg IP, Goldfarb DS. Optimum nutrition for kidney stone disease. Adv Chronic Kidney Dis 2013;20:165-174.

40. Remer T, Manz F. Potential renal acid load of foods and its influence on urine pH. J Am Diet Assoc 1995;95:791-797.

41.de Planter Bowes A, Church HN, Pennington JA. Bowes and Church's food values of portions commonly used. 17th ed. Philadelphia: Lippincott Williams and Wilkins; 1998.

42.Mahan LK, Escott-Stump S. Krause's food, nutrition, and diet therapy. Philadelphia: WB Saunders; 2000.

43.Saravakos P, Kokkinou V, Giannatos E. Cystinuria: current diagnosis and management. Urology 2014;83:693-699.

44. Rodriguez LM, Santos F, Malaga S, Martinez V. Effect of a low sodium diet on urinary elimination of cystine in cystinuric children. Nephron 1995;71:416-418.

45.Lindell A, Denneberg T, Edholm E, Jeppsson JO. The effect of sodium intake on cystinuria with and without tiopronin treatment. Nephron 1995;71:407-415. 
46.Jaeger P, Portmann L, Saunders A, Rosenberg LE, Thier SO. Anticystinuric effects of glutamine and of dietary sodium restriction. N Engl J Med 1986;315:1120-1123.

47.Parks JH, Goldfisher E, Asplin JR, Coe FL. A single 24-hour urine collection is inadequate for the medical evaluation of nephrolithiasis. J Urol 2002;167:1607-1612.

48. Nayan M, Elkoushy MA, Andonian S. Variations between two 24-hour urine collections in patients presenting to a tertiary stone clinic. Can Urol Assoc J 2012;6:30-33.

49. Fink HA, Wilt TJ, Eidman KE, Garimella PS, MacDonald R, Rutks IR, Brasure M, Kane RL, Ouellette J, Monga M. Medical management to prevent recurrent nephrolithiasis in adults: a systematic review for an American College of Physicians Clinical Guideline. Ann Intern Med 2013;158:535-543.

50.Sakhaee K, Nicar M, Hill K, Pak CY. Contrasting effects of potassium citrate and sodium citrate therapies on urinary chemistries and crystallization of stone-forming salts. Kidney Int 1983;24:348-352.

51.Pak CY, Peterson R, Sakhaee K, Fuller C, Preminger G, Reisch J. Correction of hypocitraturia and prevention of stone formation by combined thiazide and potassium citrate therapy in thiazideunresponsive hypercalciuric nephrolithiasis. Am J Med 1985;79:284-288.

52.Lemann J Jr, Gray RW, Pleuss JA. Potassium bicarbonate, but not sodium bicarbonate, reduces urinary calcium excretion and improves calcium balance in healthy men. Kidney Int 1989;35:688-695.

53. Barcelo P, Wuhl O, Servitge E, Rousaud A, Pak CY. Randomized double-blind study of potassium citrate in idiopathic hypocitraturic calcium nephrolithiasis. J Urol 1993;150:1761-1764.

54.Ettinger B, Tang A, Citron JT, Livermore B, Williams T. Randomized trial of allopurinol in the prevention of calcium oxalate calculi. N Engl J Med 1986;315:1386-1389.

55. Favus MJ, Coe FL. The effects of allopurinol treatment on stone formation on hyperuricosuric calcium oxalate stone-formers. Scand J Urol Nephrol Suppl 1980;53:265-271.

56.Norman RW. Metabolic evaluation of stone disease patients: a practical approach. Curr Opin Urol 2001;11:347-351.

57.Lifshitz DA, Shalhav AL, Lingeman JE, Evan AP. Metabolic evaluation of stone disease patients: a practical approach. J Endourol 1999;13:669-678.

58.Low RK, Stoller ML. Uric acid-related nephrolithiasis. Urol Clin North Am 1997;24:135-148.

59. Maalouf NM, Cameron MA, Moe OW, Sakhaee K. Novel insights into the pathogenesis of uric acid nephrolithiasis. Curr Opin Nephrol Hypertens 2004;13:181-189.

60.Barbey F, Joly D, Rieu P, Mejean A, Daudon M, Jungers P. Medical treatment of cystinuria: critical reappraisal of longterm results. J Urol 2000;163:1419-1423.

61. Martinez-Pineiro JA, de Iriarte EG, Armero AH. The problem of recurrences and infection after surgical removal of staghorn calculi. Eur Urol 1982;8:94-101.

62.Jarrar K, Boedeker RH, Weidner W. Struvite stones: long term follow up under metaphylaxis. Ann Urol (Paris) 1996;30:112117.
63. Griffith DP, Gleeson MJ, Lee H, Longuet R, Deman E, Earle N. Randomized, double-blind trial of Lithostat (acetohydroxamic acid) in the palliative treatment of infection-induced urinary calculi. Eur Urol 1991;20:243-247.

64. Taylor EN, Stampfer MJ, Curhan GC. Obesity, weight gain, and the risk of kidney stones. JAMA 2005;293:455-462.

65. Powell CR, Stoller ML, Schwartz BF, Kane C, Gentle DL, Bruce JE, Leslie SW. Impact of body weight on urinary electrolytes in urinary stone formers. Urology 2000;55:825-830.

66.Ekeruo WO, Tan YH, Young MD, Dahm P, Maloney ME, Mathias BJ, Albala DM, Preminger GM. Metabolic risk factors and the impact of medical therapy on the management of nephrolithiasis in obese patients. J Urol 2004;172:159-163.

67.Abate N, Chandalia M, Cabo-Chan AV Jr, Moe OW, Sakhaee $\mathrm{K}$. The metabolic syndrome and uric acid nephrolithiasis: novel features of renal manifestation of insulin resistance. Kidney Int 2004;65:386-392.

68.Lee YC, Huang SP, Juan YS, Huang TY, Liu CC. Impact of metabolic syndrome and its components on kidney stone in aging Taiwanese males. Aging Male 2016;19:197-201.

69. Heidenreich A, Desgrandschamps F, Terrier F. Modern approach of diagnosis and management of acute flank pain: review of all imaging modalities. Eur Urol 2002;41:351-362.

70.Park SH, Kim KD, Moon YT, Myung SC, Kim TH, Chang IH, Kwon JK. Pilot study of low-dose nonenhanced computed tomography with iterative reconstruction for diagnosis of urinary stones. Korean J Urol 2014;55:581-586.

71.Sameh WM. Value of intravenous urography before shockwave lithotripsy in the treatment of renal calculi: a randomized study. J Endourol 2007;21:574-577.

\section{Peer Reviewers' Commentary}

요로결석은 비뇨의학 분야에서 환자군의 규모가 매우 크고 학 문적으로 중요도가 높은 질환이다. 질환 발현의 다양성과 높은 재발률, 합병증 발생률로 인해 환자의 삶의 질 저하뿐만 아니 라 사회적 비용도 매우 높다. 이 논문에서는 요로결석의 치료 이상으로 중요하다고 할 수 있는 예방과 관리에 대한 최신 지 식을 포괄적이면서도 자세하게 정리하여 기술해 주고 있다. 재 발생 요로결석 환자 진료 시에 재발을 예방하고 관리하기 위 해 임상의사가 시행해야 하는 검사들과 검사의 해석, 추가 검 사 등에 대한 적절한 정보를 담고 있으며, 환자에게 설명되어 야 하는 식이 관리, 약물치료에 대한 정보 역시 중요하게 다뤄 지고 있다. 이 논문은 비뇨의학과 의사 뿐 아니라 다른 전공 임 상의들도 흔하게 접하는 요로결석 환자를 진료함에 있어 좋은 지침을 제공할 것으로 판단된다.

[정리: 편집위원회] 